Mycologia, 99(1), 2007, pp. 78-87.

C 2007 by The Mycological Society of America, Lawrence, KS 66044-8897

\title{
Penicillium astrolabium and Penicillium neocrassum, two new species isolated from grapes and their phylogenetic placement in the $\boldsymbol{P}$. olsonii and $\boldsymbol{P}$. brevicompactum clade
}

Rita Serra

Centro de Engenharia Biológica, Universidade do Minho, Campus de Gualtar, 4710-057 Braga, Portugal

Stephen W. Peterson ${ }^{1}$

Microbial Genomics and Bioprocessing Research Unit, National Center for Agricultural Utilization Research, Agricultural Research Service, U.S. Department of Agriculture, 1815 N. University St., Peoria, Illinois 61604

Abstract: We describe two new terverticillate Penicillium species isolated from grapes on the basis of phenotypic and phylogenetic differences from known species. The strains were isolated in the course of a study to establish the mycobiota of grapes in Portugal. Penicillium astrolabium is phenotypically similar to $P$. olsonii but differs from it by two cultural characters, growth rates and the colony reverse color. $P$. neocrassum is similar to $P$. brevicompactum but is readily distinguished by sclerotia production. Phylogenetically $P$. astrolabium and $P$. neocrassum are placed respectively in the $P$. olsonii and $P$. brevicompactum clade. Multilocus analysis confirmed the genetic distinctiveness of both species. The parsimony trees obtained for ITS-lsu rDNA region and two protein coding genes, calmodulin and $\beta$-tubulin, show congruence for all the species in the Olsonii series: P. brevicompactum, P. bialowiezense, P. olsonii, $P$. astrolabium and $P$. neocrassum, indicating that these taxa are genetically well isolated.

Key words: DNA sequences, fungi, grapes, taxonomy

\section{INTRODUCTION}

An extensive survey was conducted to determine the mycobiota colonizing grapes in Portugal with emphasis on Aspergillus and Penicillium species to establish the species responsible for ochratoxin A production in grapes and wine (Serra et al 2005). Nearly 1000 strains of Aspergillus and Penicillium were isolated. Grapes proved to be an interesting source of fungal biodiversity and a new black Aspergillus species

Accepted for publicatioin 30 October 2006.

${ }^{1}$ Corresponding author. E-mail: peterssw@ncaur.usda.gov isolated from berries, A. ibericus, was described for the first time (Serra et al 2006a).

A few isolates of Penicillium were not identified satisfactorily using the available monographs of Raper and Thom (1949), Pitt (1980, 1985) and Ramirez (1982). The strains were assigned on the basis of penicillus structure to the subgenus Penicillium, section Coronata Pitt series Olsonii Pitt, which contains three accepted species (Samson and Frisvad 2004): $P$. bialowiezense (synonym of $P$. biourgeianum), $P$. brevicompacum and $P$. olsonii. Peterson (2004) showed that these species are phylogenetically distinct but closely related. Nevertheless the isolates from grapes differed from the described species in evident cultural characters. To achieve an accurate identification, the strains were barcoded using the internal transcribed spacer region (ITS) and ca. 650 nucleotides of the large subunit rDNA (ID region) and compared to sequences from known species using BLAST searches of GenBank and unpublished sequences (Peterson unpublished). The strains were related to $P$. brevicompactum and $P$. olsonii but yet were distinctive at this locus.

We describe two new terverticillate species in the series Olsonii and compare them with the previously described species. The phylogenetic placement of the putative new species was assessed with multilocus DNA sequence analysis of sequences from the ID region and the protein coding loci calmodulin and $\beta$ tubulin.

\section{MATERIALS AND METHODS}

Fungal cultures. $-P$. astrolabium and $P$. neocrassum together with a sclerotial strain of $P$. olsonii were isolated from Portuguese grape berries by plating methods without surface disinfection as described in detail by Serra et al (2005). The origin of these and all the strains used for comparison is provided (TABLE I). The strains are stored in the Agriculture Research Service (ARS) Culture Collection (NRRL) and in Micoteca da Universidade do Minho culture collection (MUM) and available on request.

Media and growth conditions. - Some isolates were examined phenotypically with the methodology of Pitt (1980). Czapek yeast extract (CYA), Blakeslee's malt extract (MEA) and G25N agar were formulated as described, and cultures were incubated under the conditions described by Pitt (1980). 
TABLE I. Origin of the Penicillium isolates included in this study sequenced for partial $\beta$-tubulin, calmodulin and ID region

\begin{tabular}{|c|c|c|c|}
\hline NRRL number & Origin & Source & Genbank Acession no.* \\
\hline \multicolumn{4}{|c|}{ Penicillium astrolabium Serra \& Peterson } \\
\hline \multirow[t]{3}{*}{35611 ex-type (= MUM 06.161) } & Portugal & wine grapes & DQ645793 вт \\
\hline & & & DQ645808 CF \\
\hline & & & DQ645804 ID \\
\hline \multicolumn{4}{|l|}{ Penicillium biourgeianum Zaleski } \\
\hline 865 ex-type & Poland & forest soil & DQ645783 ${ }^{\mathrm{BT}}$ \\
\hline 2013 & Germany & mushroom spawn & DQ645786 \\
\hline 28149 & USA & dead agaric on logs & DQ645790 вт \\
\hline 32205 & USA & fresh coconut & DQ645791 вт \\
\hline 32207 & USA & Christmas fern & DQ645792 ${ }^{\text {вT }}$ \\
\hline \multicolumn{4}{|l|}{ Penicillium brevicompactum Dierckx } \\
\hline 859 & USA & decaying mushroom & DQ645800 вт \\
\hline 2011 ex-neotype & unknown & unknown & DQ645784 \\
\hline 2012 & unknown & paprika & DQ645785 вт \\
\hline 28120 & USA & wood decay fungus & DQ645789 вт \\
\hline 28139 & USA & wood decay fungus & DQ645795 \\
\hline \multicolumn{4}{|l|}{ Penicillium canescens } \\
\hline \multirow[t]{3}{*}{35656} & USA & cheek pouch of kangaroo rat & DQ658166 ${ }^{\text {вт }}$ \\
\hline & & & DQ658167 CF \\
\hline & & & DQ658168 \\
\hline \multicolumn{4}{|c|}{ Penicillium neocrassum Serra \& Peterson } \\
\hline \multirow[t]{3}{*}{35639 ex-type (= MUM 06.160) } & Madeira Isl., Portugal & wine grapes & DQ645794 вт \\
\hline & & & DQ645809 CF \\
\hline & & & DQ645805 ID \\
\hline \multirow[t]{3}{*}{35648 (= MUM 06.162) } & Madeira Isl., Portugal & wine grapes & DQ645802 вт \\
\hline & & & DQ645810 CF \\
\hline & & & DQ645806 ${ }^{\mathrm{ID}}$ \\
\hline \multicolumn{4}{|l|}{ Penicillium olsonii Bainier \& Sartory } \\
\hline 5267 & unknown & unknown & DQ645787 вт \\
\hline 5916 & unknown & unknown & DQ645788 \\
\hline 6446 & Russia & soil & DQ645796 \\
\hline \multirow[t]{3}{*}{13058 ex-type } & Austria & roots in Picea & DQ645797 \\
\hline & & & DQ658165 CF \\
\hline & & & $\widehat{A F} 454076$ ID \\
\hline 31467 & Mexico & coffee berry borer & DQ645798 ${ }^{\text {вт }}$ \\
\hline \multirow{3}{*}{35612} & Portugal & wine grapes & DQ645801 \\
\hline & & & DQ645807 CF \\
\hline & & & DQ645803 ${ }^{\mathrm{ID}}$ \\
\hline
\end{tabular}

* BT $\beta$ - tubulin; ${ }^{\mathrm{CF}}$ calmodulin; ${ }^{\mathrm{ID}}$ ID region. Accession numbers for loci not explicitly listed here are found in Peterson (2004).

Microscopy. - SEM was performed on agar blocks of cultures grown in MEA fixed overnight in osmium tetroxide, dehydrated in a series of ethanol rinses of increasing concentrations, critical-point dried and sputter coated with gold-paladium in a JEOL scanning electron microscope following the procedure of Peterson (1992). Light microscopic measurements and examinations were made with a Zeiss axioscope and Kodak 420B camera on fungal material mounted in $0.5 \%$ low melting temperature agarose and water. Digital images from both sources were adjusted for brightness/contrast and fitted into composite plates using Adobe Photoshop 6.01.
Molecular methods.-DNA was isolated from mycelium using a variation of the method of Peterson et al (2005). Instead of vortexing mycelium and glass beads in $15 \mathrm{~mL}$ disposable tubes for 45-60 s, the process was scaled down so that the vortexing could be accomplished in a $2 \mathrm{~mL}$ screwcap microcentrifuge tube. Using a 24-tube holder for the vortex mixer, up to 24 samples could be processed simultaneously and the period of cell breakage was increased to $10 \mathrm{~min}$. Other conditions and processes were similarly scaled-down modifications of the basic protocol (Peterson et al 2005).

DNA from the $\beta$-tubulin locus was amplified with the 
protocol and primers of Glass and Donaldson (1995) from calmodulin and the ITS and lsu-rDNA (ID) region with the methods of Peterson et al (2005). The amplified fragments were purified with the Multiscreen PCR system of Millipore (Billerica, Massachusetts) and sequenced with dye-labeled dideoxy terminator (v 3.1) and the ABI model 3730 DNA sequencer (both from Applied Biosystems Inc, Foster City, California)

Complementary DNA strands were compared and sequencing error corrected with Sequencher (Gene Codes, Ann Arbor, Michigan). Corrected sequences initially were aligned with Clustal W (Thompson et al 1994), examined and fine aligned with a text editor.

PAUP* (Swofford 2002) was used to analyze the DNA sequence data, with the parsimony criterion, random sequence addition, and with maximum trees set at 1000 in an heuristic search. Bootstrap analysis used the same criteria except that sequence addition was "as-is". Tree files were examined with Treeview (Page 1996) and redrawn for publication using CorelDraw. Datasets and results have been deposited in TreeBase (http://www.treebase.org) and sequences have been deposited in GenBank (http:// www.ncbi.nlm.nih.gov).

\section{TAXONOMY}

Examination of morphological characters combined with the analysis of DNA sequences revealed that the terverticillate Penicillium strains related to P. brevicompactum and $P$. olsonii do not match any of the species described to date. Two new species, $P$. astrolabium and P. neocrassum, are proposed.

Penicillium astrolabium R. Serra \& S.W. Peterson, sp. nov. $\quad$ Figs. 1-9

Coloniae crescentes post 7 dies in CYA ad 25 C $20-27 \mathrm{~mm}$ diam, radialiter et anulariter sulcatae, per mediam partem depressae, moderate profundae, densae, textura superficiei velutinosa ad granularis, margines profundae et curvatae, mycelium album vel interdum pallide-flavum; conidiogenesis magna per aream totam coloniae, celandino-viride (Ridgway Pl. XLVII), sudor moderatus per mediam partem coloniae productus est; primum perspicuus, deinde rubro-brunnea quando maturant, pigmentum brunneum et dissolubile adest, clarius quando maturant; pars reversa nigro-brunnea ad nigra, decolor solum in marginibus coloniae. Incubata ad $5 \mathrm{C}$ et ad 37 $\mathrm{C}$ in CYA incrementem nullum post 7 dies. In G25N coloniae mediae 17-25 mm diam, irregulariter sulcatae et plicatae, cum propagine profunda mycelii albi a penicillis dispersis velata, textura superficiei velutinosa ad granularis, conidiogenesis moderata, piso-viridis ad celandino-viridis. Sudor et pigmentum dissolubile absunt, facies reversa pallida, obscure nigroviridis per mediam partem (Ridgway, Pl. XLI). Conidiophora portata in hyphis sub superficie orientibus, maxima, stipites fere 500-2000 $\times$ 4.0-6.0 um, distincti et aliquando cristati in marginibus, tenuiter tunicati, terminantes in penicillis dense appressis et mulitramulatis, plerumque terverticillati sed interdum quaterverticillati, 2-5 rami per stipitem, 9-13(-20) $\times 4.0-5.0 \mu \mathrm{m}$ cum penicillis distincte multiramulatis; metulae in verticillis 3-5 coninentibus, $(8.0-) 9-13 \times 3.0-4.0 \mu \mathrm{m}$; phialides in verticillis 5-6 continentibus, ampulliformes, plerumque $8-10 \times 2.5-3.0 \mu \mathrm{m}$, cum collulis brevibus; conidia ellipsoidea, 3.0-4.0 $\times 2.5-3.0 \mu \mathrm{m}$, tenuiter tunicata vel in extremis asperata, portata in catenis confusis.

Colonies grown $7 \mathrm{~d}$ on CYA (FIG. 1) at $25 \mathrm{C}$ attain 20-27 mm diam, are radially and annularly sulcate, centrally depressed, moderately deep, dense, surface texture velutinous to granular, margins deep and wavy, mycelium white or light yellow in some areas; conidiogenesis heavy over the whole colony area, celandine green (Ridgway Pl. XLVII), limited amounts of exudate produced at the center of the colony, clear at first, then becoming reddish brown with age; brown soluble pigment produced becoming more evident with age; reverse blackish brown to black (FIG. 4), paler only at colony margins.

Colonies grown $7 \mathrm{~d}$ on MEA, at $25 \mathrm{C}$ attain 15$16 \mathrm{~mm}$ diam, are plane sometimes centrally raised, moderately deep of granular texture (FIG. 2); margins narrow, irregular; mycelium inconspicuous, white; subsurface mycelium black (FIG. 5), visible on the obverse at punctuated areas surrounding colony center and at margin areas (FIG. 3), conidiogenesis heavy, celandine green, exudates and soluble pigment absent; reverse deep slate-olive to dull greenish black (Ridgway Pl. XLVII) (FIG. 4).

When incubated at $5 \mathrm{C}$ and at $37 \mathrm{C}$ in CYA, no growth was observed in $7 \mathrm{~d}$. On G25N medium colonies attain $17-25 \mathrm{~mm}$ diam, are irregularly sulcate and plicate, composed of a deep layer of white mycelium covered with scattered penicilli, surface texture velutinous to granular; conidiogenesis light, pea to celandine green, no exudates and soluble pigment produced; reverse pale with a dull blackish green (Ridgway Pl. XLI) center.

Conidiophores borne from subsurface hyphae, large, with stipes typically 500-2000 $\times$ 4.0-6.0 $\mu \mathrm{m}$, occurring as long tuffs at some marginal areas, smooth walled, terminating in closely appressed multiramulate penicilli (FIGS. 6-7), usually terverticillate but occasionally quaterverticillate; rami $2-5$ per stipe, 9-13(-20) $\times$ 4.0-5.0 $\mu \mathrm{m}$; metulae in verticils of 3-5, measuring (8.0-)9-13 × 3.0-4.0 $\mu \mathrm{m}$; phialides in verticils of 5-6, ampulliform, commonly $8-10 \times 2.5-$ $3.0 \mu \mathrm{m}$, with short collula; conidia ellipsoidal, 3.0-4.0 $\times 2.5-3.0 \mu \mathrm{m}$, with walls smooth or finally roughened (FIGS. 8-9), borne in disordered chains.

HOLOTYPE: BPI 872160 here designated, deposited in the U.S. National Fungus Collection, is a dried culture of NRRL 35611 on MEA and CYA. Culture extype: NRRL 35611.

Etymology. astrolabium from astrolabio, the navigation instrument used by Portuguese sailors to cross the 

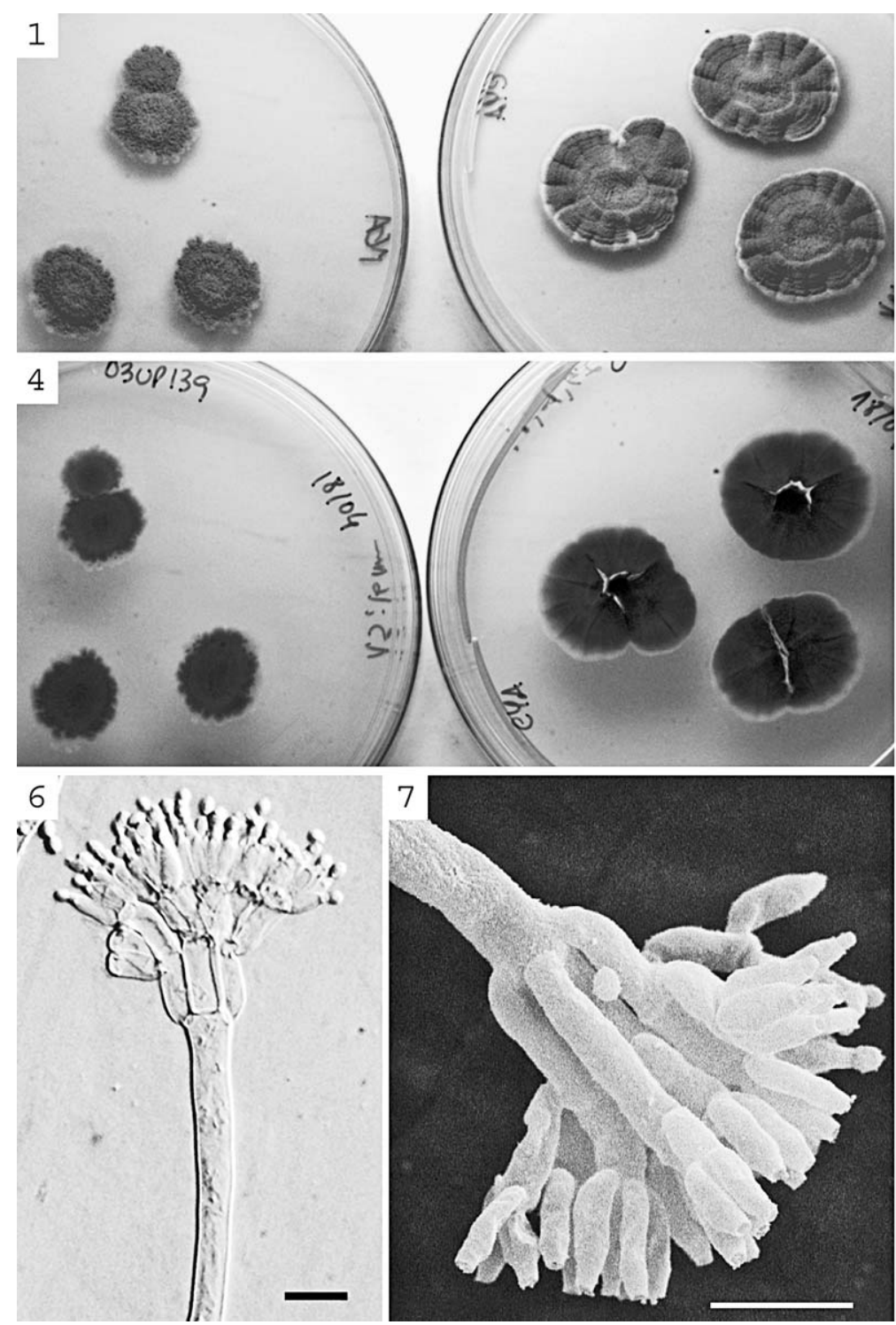

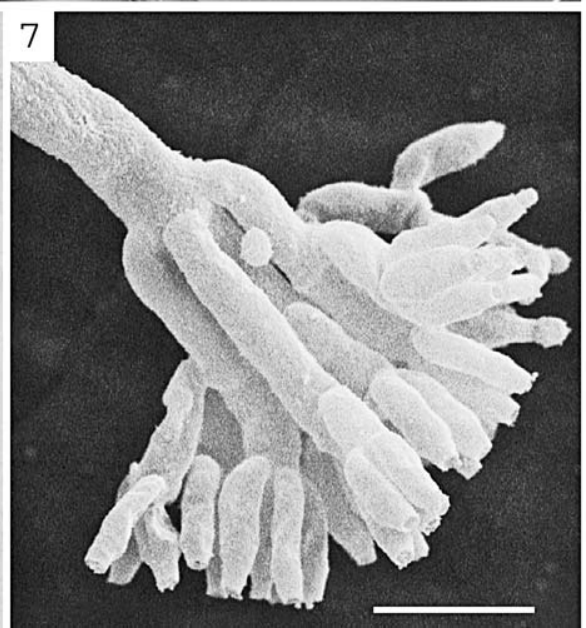

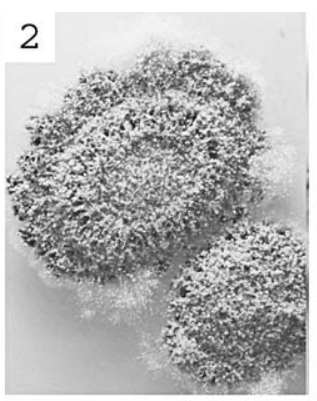
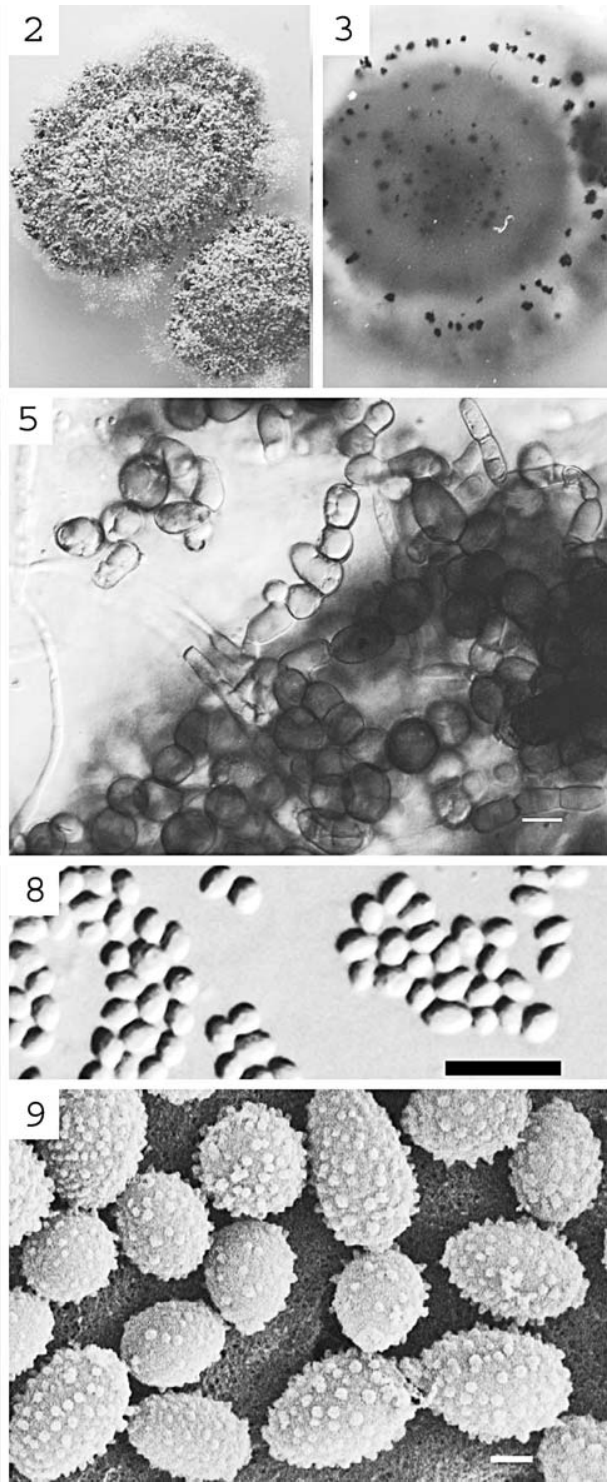

FIGS. 1-9. Penicillium astrolabium, NRRL 35611. 1. Colonies on MEA and CYA after 7 d. 2. Detail of colony obverse on MEA where black hyphae masses are visible. 3. Colony reverse on MEA after $12 \mathrm{~d}$ incubation with black hyphae masses on agar subsurface. 4. Dark pigmentation in colonies reverse visible in MEA and CYA. 5. Dark hyphae. 6-7. Penicilli. 8-9. Conidia. Bar in $5-8=10 \mu \mathrm{m}$, FIG. 9. $=1 \mu \mathrm{m}$.

seas and discover the New World, in honor of the transatlantic cooperation that resulted in describing the new species.

Origin of strains. HOLOTYPE. PORTUGAL. RIBATEJO, Almeirim. Vineyard located $39^{\circ} 12^{\prime} 34^{\prime \prime} \mathrm{N}$ and $8^{\circ} 37^{\prime} 46^{\prime \prime} \mathrm{W}$, on healthy grapes, 4 Oct 2001, Rita Serra O3UP139. Isotype deposited in the MUM culture collection, Braga, Portugal.

Additional specimens examined. This species is known from the type strain only.

Commentary. Microscopically this species resembles $P$. olsonii but differs from it in cultural characters. The growth rates of $P$. astrolabium in CYA and MEA are slower than $P$. olsonii, and the colony reverse is dark olive or brown to black. Black hyphae masses are clearly visible on the reverse with age.

Penicillium neocrassum R. Serra \& S.W. Peterson, sp. nov.

FIGS. 10-20

Coloniae crescentes post 7 dies in CYA ad 25 C 23-26 mm diam, radialiter sulcatae cum sulco anulario circum mediam partem elevatam coloniae, interdum crateriformes, moderate profundae, compositae de propagine scleroticorum brunneorum et confinium in superficie agaris quae dominant aspectum coloniae, cum penicillis dispersis et superimpositis, textura superficiei velutinosa, margines albae, irregulares, angustae, mycelium album; conidiogenesis moderata, gnaphalium viride ad theae-viride (Ridgway 

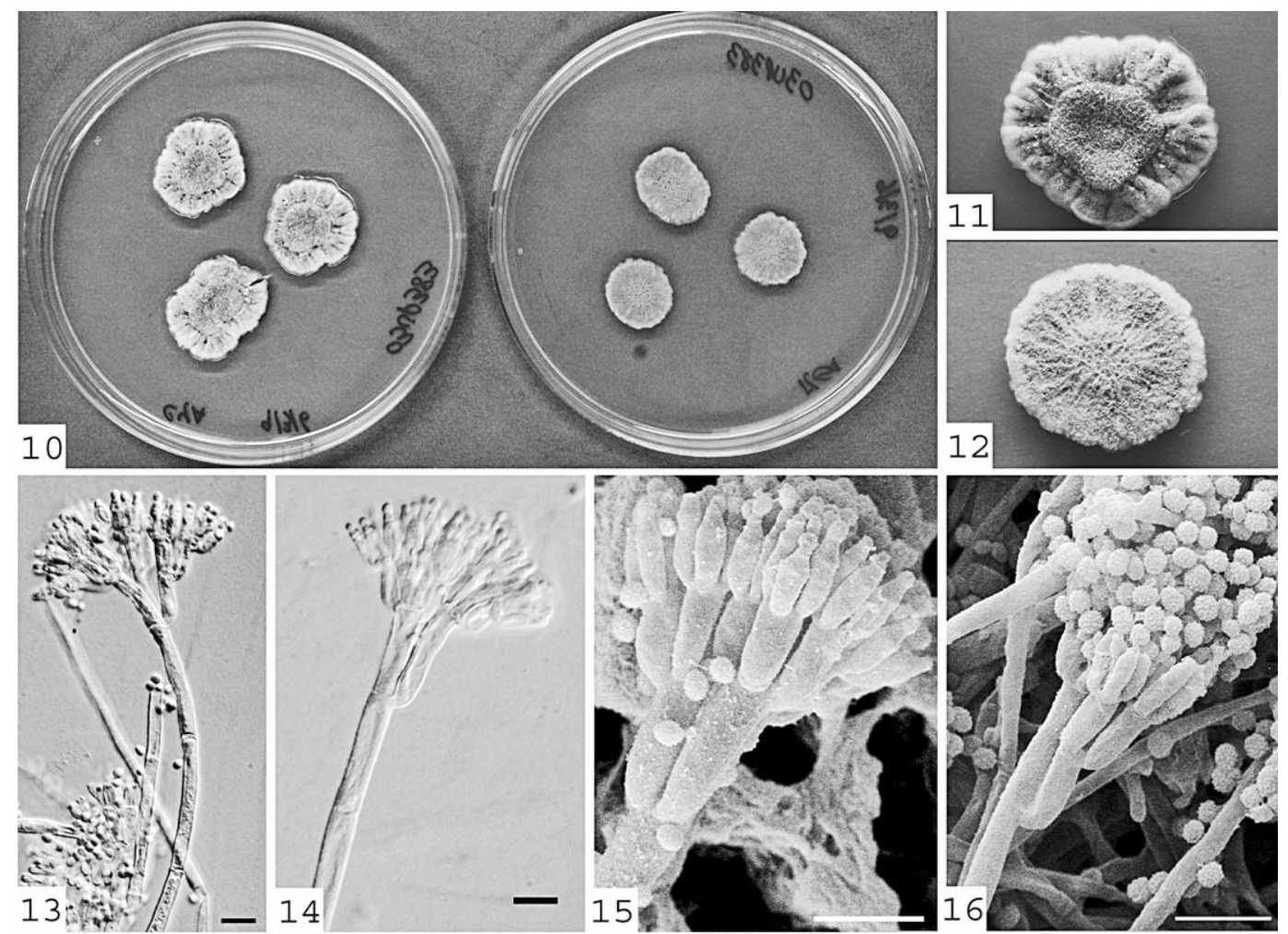

12
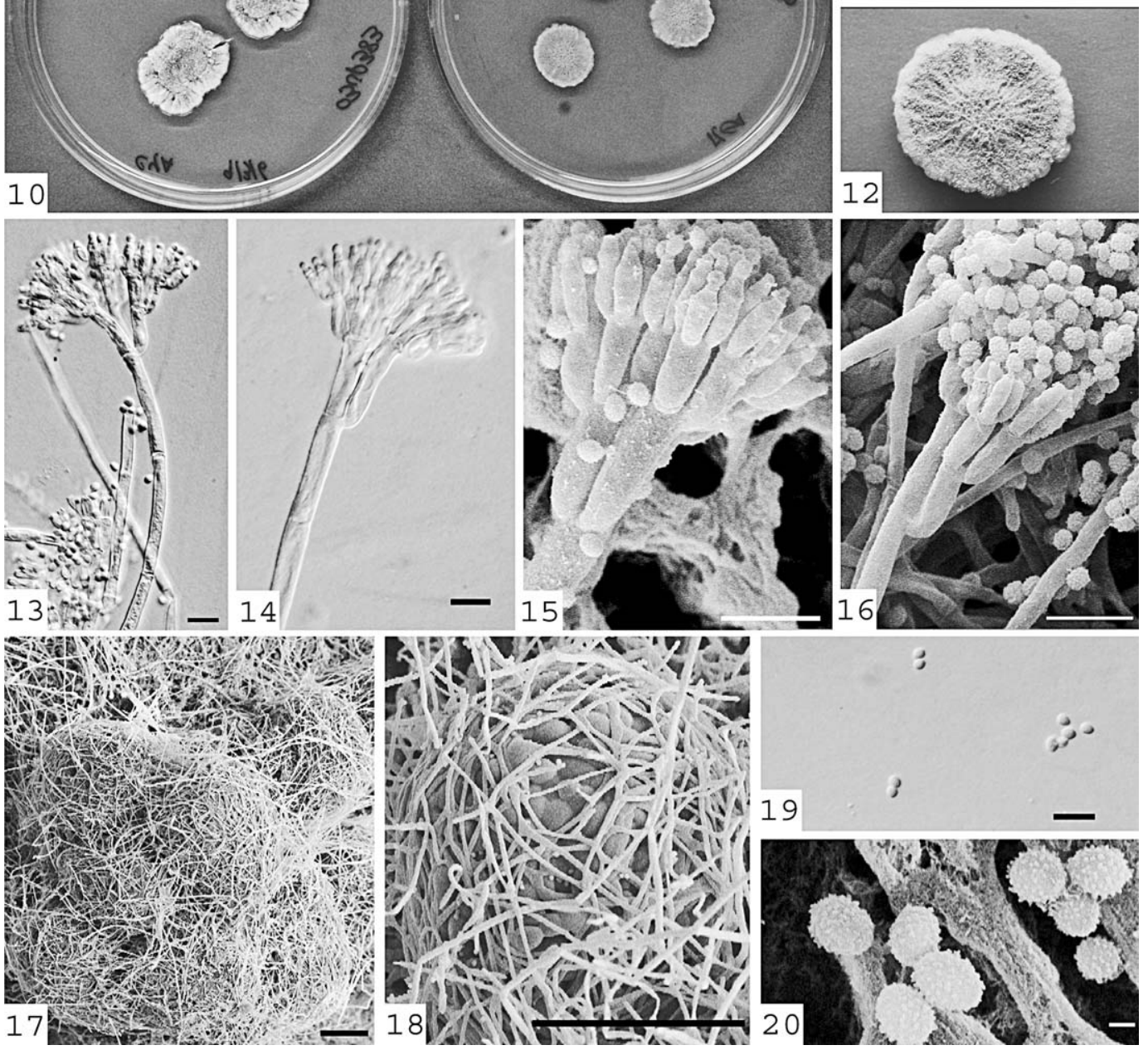

FIGS. 10-20. Penicillium neocrassum NRRL 35639. 10. Colonies on MEA and CYA after 7 d. 11. Detail of colony on CYA. 12. Detail of colony on MEA. 13-16. Penicillus. 17-18. Sclerotia. 19-20. Conidia. Bar in Figs 13-16=10 16 m, FIg 17-18=100 $\mu \mathrm{m}$, FIG $19=10 \mu \mathrm{m}$, FIG $20=1 \mu \mathrm{m}$.

Pl. XLVII), sudor moderatus et perspicuus in margine coloniae productus est; pigmentum dissolubile abest; pars reversa fusce-rava ad nigro-brunnea (Ridgway Pl. XLV), pallida in marginibus coloniarum. Incubata ad $5 \mathrm{C}$ et ad 37 $\mathrm{C}$ in CYA incrementem nullum post 7 dies. In G25N coloniae 22-24 mm diam, irregulariter sulcatae et centraliter convolutae, moderate profundae, textura superficiei velutinosa, margines extendentes $2-3 \mathrm{~mm}$ sub superficie, mycelium album et sclerotia alba ad brunneo-alba circumfundens, conidiogenesis moderata, theae-viridis. Sudor et pigmentum absunt, facies reversa brunnea per mediam partem.

Sclerotia ellipsoidea ad forma irregularia, fere 200$360 \mu \mathrm{m}$ per axim longiorem, rapide sclerotioidea, primum pallida, deinde brunnea, fusce-rava ad nigro-brunnea
(Ridgway Pl. XLV) in CYA, Kaiser-brunnea ad castaneobrunnea in MEA (Ridgway Pl. XIV), pallide brunneo-alba in G25N. Status teleomorphosis ignotus.

Conidiophora portata in hyphis sub superficie orientibus, stipes fere longus et latus, 500-800 $\times 4.5-6.0 \mu \mathrm{m}$, tenuiter tunicatus, portans penicillos confertos et late terverticillatos, fere minus quam $40 \mu \mathrm{m}$ longitudine et $35-$ $53 \mu \mathrm{m}$ latitudine, interdum cum penicillis quaterverticillatis et biverticillatis, rami singuli, breves et lati, 11-18 $\times 4.0$ $5.0 \mu \mathrm{m}$, aliquando in apice inflati, appressi prope basim et saepe ab axi averti, metulae portatae in uvis manifeste diversis 5-7 continentibus, breves et latae, 9-12 × 3.5$4.0 \mu \mathrm{m}$, plerumque in apice inflatae; phialides in verticillis diversis $6-8$ continentibus, ampulliformes, plerumque 7-10 $\times$ 2.2-3.0 $\mu \mathrm{m}$, cum collulis brevibus; conidia ellipsoidea, 
2.5-3.5 $\times 2.0-2.5 \mu \mathrm{m}$, tenuiter tunicata vel in extremis asperata, portata in catenis confusis.

Colonies grown $7 \mathrm{~d}$ on CYA at 25 C (FIGS. 10-11) attain 23-26 mm diam, are radially sulcate with an annular furrow around the raised colony central area, occasionally crateriform, moderately deep, composed of a layer of contiguous brown sclerotia on the agar surface that dominate the colony appearance surmounted by scattered penicilli, surface texture velutinous, margins white, irregular, narrow; mycelium white; conidiogenesis moderate, gnaphalium green to tea green (Ridgway Pl. XLVII), limited amounts of clear exudate produced at the margins of the colony; soluble pigment absent; reverse dusky drab to blackish brown (Ridgway Pl. XLV), pale at colony margins.

Colonies grown $7 \mathrm{~d}$ on MEA at $25 \mathrm{C}$ (Figs. 10 and 12) attain $15-17 \mathrm{~mm}$ diam, are plane but centrally raised, moderately deep of velutinous texture with abundant clusters of brown sclerotia (FIG. 17) produced on the agar surface surmounted by scattered penicilli; margins narrow, irregular; mycelium inconspicuous, white; conidiogenesis moderate in colors similar to those on CYA, heavier between clusters of sclerotia formed in radial lines and at colony margins, exudates and soluble pigment absent; reverse pale brown darker at the center.

When incubated at $5 \mathrm{C}$ and $37 \mathrm{C}$ in CYA, no growth was observed in $7 \mathrm{~d}$. On G25N colonies attain 22 $24 \mathrm{~mm}$ diam, irregularly sulcate and centrally convolute, moderately deep, surface texture velutinous, margins extending 2-3 $\mathrm{mm}$ subsurface; mycelium white enveloping white to cream sclerotia, conidiogenesis moderate, tea green, no exudates and soluble pigment produced; reverse pale brownish at the center.

Sclerotia (FIGS. 17-18) ellipsoidal to irregular in shape, usually $200-360 \mu \mathrm{m}$ in long axis, rapidly becoming sclerotioid, pale at first, then brown, dusky drab to blackish brown (Ridgway Pl. XLV) on CYA and Kaiser Brown to Chestnut Brown on MEA (Ridgway XIV), but pale cream on G25N. Teleomorphic state not known.

Conidiophores (FIGs. 13-16) borne from subsurface hyphae, stipes usually long and broad, 500-800 $\times$ 4.5-6.0 $\mu \mathrm{m}$, smooth walled, bearing compact, broad terverticillate penicilli, usually less than $40 \mu \mathrm{m}$ long and $35-53 \mu \mathrm{m}$ broad, with quaterverticillate and biverticillate penicilli usually evident also; rami usually borne singly, short and broad, 11-18 × 4.0-5.0 $\mu \mathrm{m}$, sometimes apically inflated, appressed at the base and often bent away from the axis, with penicilli distinctively multirramulate also; metulae borne in markedly divergent clusters of 5-7, short and broad, 9-12 $\times$ $3.5-4.0 \mu \mathrm{m}$, typically apically inflated; phialides in divergent verticils of $6-8$, ampulliform, commonly $7-$
$10 \times 2.2-3.0 \mu \mathrm{m}$, with short collula; conidia ellipsoidal, 2.5-3.5 $\times 2.0-2.5 \mu \mathrm{m}$, with walls smooth or finally roughened (FIGS. 19-20), borne in disordered chains.

HOLOTYPE: BPI 872161 here designated, deposited at the U.S. National Fungus Collection is a dried culture of NRRL 35639 on MEA and CYA. Culture extype: NRRL 35639.

Etymology. neocrassum related to $P$. crassum Sopp, the only species that was ever described to produce sclerotia in the $P$. brevicompactum series but not typified.

Origin of strains. HOLOTYPE: PORTUGAL. MADEIRA ISLAND, Câmara de Lobos. Vineyard at $32^{\circ} 38^{\prime} \mathrm{N}$ and $16^{\circ} 56^{\prime} \mathrm{W}$, on healthy grapes, 8 Sep 2003, Rita Serra O3UP383. Isotype deposited in the MUM culture collection, Braga, Portugal.

Additional specimens examined: NRRL 35648 (MUM 06.162), PORTUGAL. MADEIRA ISLAND, Câmara de Lobos, from healthy grapes, 8 Aug 2003, Rita Serra O3UP426 (isolated from a different Vitis vinifera plant than the ex-type strain). The growth rates were slightly slower on all culture media achieving 19-21 mm diam on CYA. Poor germination was observed at $5 \mathrm{C}$. Colony texture on CYA is floccose and the conidial color is paler than the type strain. Sclerotia were observed after $7 \mathrm{~d}$ growth on MEA only but were clearly visible on CYA and G25N after $12 \mathrm{~d}$. A higher proportion of multirramulate penicilli was observed than in the type strain.

Commentary. Microscopically this species resembles $P$. brevicompactum but penicilli typical of $P$. olsonii are evident also. The colonies resemble those of $P$. brevicompactum and differ from it mainly by the production of sclerotia visible at least on MEA.

\section{RESULTS}

The total length of the ID region DNA sequence of $P$. astrolabium NRRL 35611 is 1148 base pairs. In BLAST search $P$. astrolabium was a 98-99\% match to the nucleotide sequences of $P$. olsonii strains, differing from $P$. olsonii at 11-13 nucleotide positions. The total length of the ID region DNA sequence of $P$. neocrassum NRRL 35639 and 35648 was respectively 1149 and 1150 base pairs. The $P$. neocrassum strains differed in one single base position. In BLAST searches $P$. neocrassum showed $99 \%$ similarity to the nucleotide sequences from $P$. brevicompactum strains, differing from $P$. brevicompactum at 5-7 nucleotide positions and had $98 \%$ similarity to $P$. bialowiezense and $P$. olsonii strains. The sclerotial strain of $P$. olsonii matched $100 \%$ with the ID sequence of the ex-type $P$. olsonii strain and differed at up to two base pairs with other P. olsonii sequences deposited in GenBank. The polymorphic sites between $P$. astrolabium/P. olsonii and $P$. neocrassum $/ P$. brevicompactum are indicated (TABle II). 
TABle II. Polymorphisms in the ID region for $P$. astrolabium and $P$. neocrassum comparatively to $P$. olsonii and $P$. brevicompactum, respectively

\begin{tabular}{|c|c|c|c|c|c|c|c|c|c|c|c|c|c|c|c|c|c|c|c|}
\hline & \multicolumn{19}{|c|}{ Nucleotide position } \\
\hline & 75 & 91 & 94 & 104 & 105 & 108 & 362 & 443 & 456 & 457 & 572 & 575 & 597 & 913 & 938 & 940 & 979 & 1017 & 1018 \\
\hline P. astrolabium 35611 & & & & $\mathrm{~A}$ & $\mathrm{~T}$ & & $\mathrm{C}$ & & A & C & A & $\mathrm{T}$ & $\mathrm{T}$ & & $\mathrm{T}$ & C & A & $\mathrm{T}$ & C \\
\hline P. olsonii 35612 & & & & & & & $\mathrm{~T}$ & & & & & & & & & & & & $\mathrm{~T}$ \\
\hline P. olsonii & & & & $\mathrm{T}$ & C & & $\begin{array}{l}\mathrm{T} \\
\mathrm{C}\end{array}$ & & $\mathrm{C}$ & $\mathrm{T}$ & G & $\mathrm{C}$ & $\mathrm{C}$ & & $\mathrm{C}$ & $\mathrm{T}$ & G & $\mathrm{C}$ & $\begin{array}{l}\mathrm{C} \\
\mathrm{T}\end{array}$ \\
\hline P. neocrassum 35639 & $\mathrm{C}$ & A & $\mathrm{T}$ & & & $\mathrm{T}$ & & $\mathrm{T}$ & $\mathrm{T}$ & & & & & A & & & & & $\mathrm{C}$ \\
\hline P. neocrassum 35648 & $\mathrm{C}$ & A & $\mathrm{T}$ & & & $\mathrm{T}$ & & $\mathrm{T}$ & $\mathrm{T}$ & & & & & G & & & & & C \\
\hline P. brevicompactum & $\mathrm{T}$ & $\begin{array}{c}\mathrm{G} \\
\mathrm{T}\end{array}$ & $\begin{array}{l}\mathrm{T} \\
\mathrm{C}\end{array}$ & & & $\mathrm{C}$ & & $\mathrm{C}$ & $\mathrm{C}$ & & & & & G & & & & & $\mathrm{T}$ \\
\hline
\end{tabular}

Nucleotide changes at the $\beta$-tubulin locus were found in both the introns and coding regions and resulted in distinct amino acid sequences even between strains of the same species. P. brevicompactum and $P$. olsonii strains had a single amino acid substitution each while $P$. bialowiezense strains had four amino acid changes. $P$. neocrassum strains did not differ in the amino acid sequence. Seven amino acid changes were observed between $P$. astrolabium and $P$. olsonii type strain and two amino acid substitutions were found between $P$. neocrassum and $P$. brevicompactum type strain. On the contrary, most of the changes detected in calmodulin DNA sequences were in the introns. No amino acid substitution was observed between $P$. astrolabium, $P$. neocrassum, $P$. olsonii and $P$. brevicompactum type strains.

Parsimony analysis of the ID region dataset produced a single most parsimonious (MP) tree. $P$. astrolabium and $P$. olsonii were placed in the same group, and $P$. bialowiezense and $P$. brevicompactum were clustered in a distinct group. $P$. neocrassum was in the same clade as $P$. bialowiezense. The bootstrap support for the $P$. astrolabium and $P$. olsonii branch was strong $(87 \%)$, but the support for $P$. bialowiezense and $P$. brevicompactum was lower $(56 \%)$. Nevertheless the support for $P$. neocrassum in a distinct clade from $P$. bialowiezense was high $(88 \%)$.

Parsimony analysis of the protein coding DNA sequence datasets produced six equally most parsimonious trees ( $\beta$-tubulin) and 25 equally most parsimonious trees (calmodulin). The protein coding DNA sequences produced phylogenetic trees better supported in boostrap analysis. The aligned $\beta$-tubulin data and calmodulin datasets both placed $P$. astrolabium and $P$. olsonii in one clade and $P$. neocrassum and $P$. brevicompactum in a distinct clade. Because trees from the three loci were congruent or at least noncontradictory, sequences were combined into a single data set. The single most parsimonious tree obtained and bootstrap values from the combined dataset are shown (FIG. 21).

\section{DISCUSSION}

P. astrolabium and P. neocrassum are well supported by phylogenetic analysis of each locus and the combined data, which clearly indicate that these species are related to $P$. olsonii and $P$. brevicompactum, respectively, but are phenotypically and genetically distinct.

Peterson (2004) showed using ID, calmodulin and elongation factor $1-\alpha$ loci that $P$. bialowiezense, $P$. brevicompactum and $P$. olsonii are distinct but closely related species using the genealogical concordance phylogenetic species concept (Taylor et al 1999). Samson and Frisvad (2004) produced a $\beta$-tubulin tree showing the same relationships as Peterson (2004) and formed their taxonomic scheme on the basis of the phylogeny. They recognize three species in the Olsonii series and supplement the DNA sequence data with secondary metabolite information also.

Most differences in the trees produced with DNA sequences of the three distinct loci were at the tips of the branches. However one branch point in the ID tree differed from the two protein coding gene trees in showing $P$. neocrassum as a sibling of $P$. bialowiezense rather than $P$. brevicompactum. Three phylogenetically informative sites in the ID dataset supported the $P$. neocrassum $/ P$. brevicompactum branching while two informative sites supported the P.neocrassum/P. bialowiezense branching. Bootstrap support for this branch was $56 \%$ of the bootstrap samples. With the low number of informative sites and low bootstrap support we view the data as being insufficient to correctly reconstruct the branching order at this node and thus the tree is noncontradictory to the trees based on protein coding loci. 


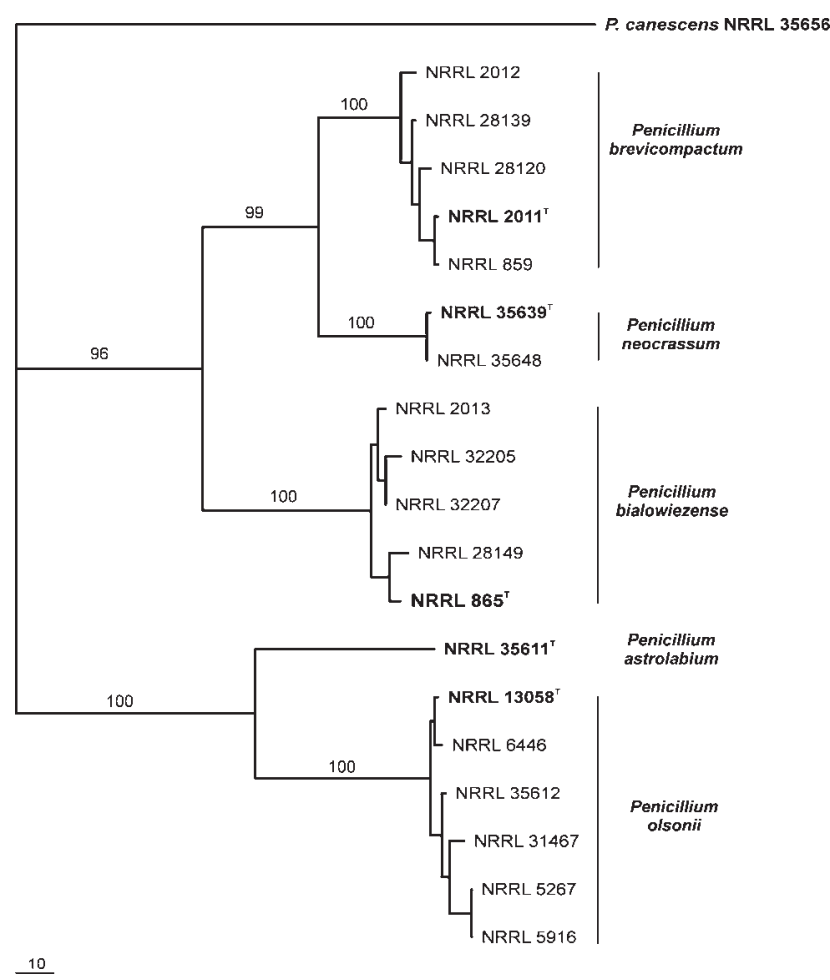

FIG. 21. Phylogenetic tree generated in a heuristic search of the combined sequence of ID locus and partial calmodulin and $\beta$-tubulin sequences. Bootstrap values based on 1000 replicates.

Although Peterson (2004) could not resolve the branching order of $P$. olsonii, $P$. brevicompactum and $P$. bialowiezense, the combined dataset analyzed (FIG. 21) are strongly supportive of $P$. brevicompactum and $P$. bialowiezense as members of the same clade, with $P$. neocrassum, Penicillium olsonii and P. astrolabium forming a distinct clade.

The phylogenetic analysis of the five species shows that they are genetically well isolated with the multilocus approach. According to Taylor and co-workers (1999), it is expected that genetically isolated species will exhibit morphological differences with time by genetic drift. Phenotypically all the Penicillium species in this group share unique terverticillate penicillin, broad and compact, with $P$. brevicompactum in one extreme, characteristically with only one rami and $P$. olsonii at the other extreme with complex multirramulate penicilli. The phenotypic differences between $P$. brevicompactum and $P$. olsonii are clear enough to recognize the species but intermediate forms are observed. Pitt (1980) described the presence of multiramulate penicilli in $P$. brevicompactum strains such as NRRL 5276 and synonymized $P$. volgaense with P. brevicompactum. Peterson (2004) confirmed with multilocus analysis that the strain NRRL 5276 fits perfectly in the $P$. brevicompactum clade but $P$. volgaense fits into and was synonymized with $P$. olsonii, demonstrating the affinities in the penicilli of both species that we clearly observed in $P$. neocrassum also.

The effects of genetic drift can be recognized in $P$. bialowiezense by the differing phenotypes among the isolates. However no obvious, fixed synapomorphies have been found that can be used reliably to identify $P$. bialowiezense isolates. The morphological recognition of $P$. astrolabium and $P$. neocrassum from its allies $P$. olsonii and $P$. brevicompactum is possible based on evident cultural characters. $P$. astrolabium produces a characteristic dark pigmentation on reverse and unusual enlarged and heavily pigmented hypha that resembles subsurface sclerotia (FIGS. 3, 5). Thom's notes on the culture 4725.1021 (Thom and Raper 1949 ) with penicilli typical of $P$. olsonii mention the production of "masses of hyphae with sporadically at least the development of sclerotia or perithecia, black, more or less submerged, brittle but so far not producing asci." This is the only mention of black hypha structures on a culture with conidiophores typical of $P$. olsonii, but it is not possible to assign Thom's culture to $P$. astrolabium because the culture was lost. The production of sclerotia by terverticillate species is uncommon. In the past few years Samson and Frisvad (2004) described some isolates of P. olsonii from tropical soil that produced sclerotia. We also isolated a sclerotial $P$. olsonii strain from Portuguese grapes. The presence of sclerotia in $P$. olsonii is rare but no differences in DNA sequences were found with the $P$. olsonii type strain. The sclerotia present in $P$. olsonii do not indicate a genetic isolation of the strains.

$P$. neocrassum's most evident cultural trait that distinguishes it from $P$. brevicompactum is the production of sclerotia. The presence of sclerotia production by a $P$. brevicompactum-like strain isolated from a rotten apple was reported by Sopp after growth on rice. This was the only time that sclerotia were reported on a culture with $P$. brevicompactum conidiophores. Sopp considered this to be sufficient to define a new species, $P$. crassum, but failed to typify the species. Thom (1930) accepted the species and Raper and Thom (1949) and Ramirez (1982) synonymized it with $P$. brevicompactum. Because no type or type culture of $P$. crassum exists we cannot be certain whether it would match $P$. neocrassum.

The phenotypic differences that allow the clear identification of $P$. astrolabium and $P$. neocrassum probably reflect selective pressures found in each species' niche that led to fixation of particular survival-critical features. Wicklow and associates (Belofsky et al 1998, Wang et al 1995, Wicklow et al 1994) have speculated on the survival value of sclerotia and secondary metabolites in different habitats. Sclero- 
tium production appears to be a variable trait but nevertheless can be a valuable indicator of new species. However due to strain variability sclerotia per se cannot be used alone for new taxon definition, as the discovery of sclerogenic $P$. olsonii demonstrates with phylogenetic analysis. The olsonii series lacks known teleomorphs. With time yellow clusters of mycelium are formed in $P$. astrolabium vaguely reminiscent of cleistothecia, but no teleomorph was found after 2 mo incubation.

Species in this tree branch are capable of growing at low water activities and are common as decaying agents. $P$. astrolabium, $P$. olsonii, $P$. brevicompactum and $P$. neocrassum were all isolated from grapes. The presence of $P$. astrolabium was rare, being isolated from one grape sample only and the presence of $P$. olsonii in grapes was also uncommon. On the contrary $P$. brevicompactum was one of the most abundant species found in berries with and without surface disinfection. $P$. bialowiezense was not morphologically recognized and therefore no information exists concerning its presence or absence in grapes. $P$. neocrassum was isolated from two out of 10 samples from a vineyard on Madeira Island that had a mycobiota distinct from the continental grapes. Penicillium species, in particular $P$. brevicompactum, were the dominant fungi isolated from Madeira Island samples (Serra et al 2006b). Some rare Penicillium species were isolated from those samples and recently were identified with the DNA barcoding methodology described in this paper (data not shown) such as $P$. adametzioides previously known from type isolate only and some undescribed sclerogenic strains related to $P$. adametzioides that will be described separately.

At this time the ecological role of $P$. astrolabium and $P$. neocrassum in vineyards is not known. The ultimate aim of the authors in describing these new taxa is to contribute to the knowledge of biodiversity in a genus useful in biotechnology and to attract attention to the existence of these easily recognizable species in future field studies and surveys. More information on the ecology and biogeographical distribution of these rare species will result.

\section{ACKNOWLEDMENTS}

Rita Serra was supported by grant SFRH/BPD/20827/2004 by Fundação para a Ciência e Tecnologia in Portugal. The authors thank Bruno Mannarelli for technical support, Michael Hertwig for the Latin translation and Isabel Santos (MUM, Portugal) for sending strains for the study.

The mention of firm names or trade products does not imply that they are endorsed or recommended by the U.S. Department of Agriculture over other firms or similar products not mentioned.

\section{LITERATURE CITED}

Belofsky GN, Gloer KB, Gloer JB, Wicklow DT, Dowd PF. 1998. New p-terphenyl and polyketide metabolites from the sclerotia of Penicillium raistrickii. J Nat Prod 61: 1115-1119.

Page RDM. 1996. Treeview: an application to display phylogenetic trees on personal computers. Computer Applications in the Biosciences 12:357-358.

Peterson SW, Vega FE, Posada F, Nagai C. 2005. Penicillium coffeae a new endophytic species isolated from a coffee plant and its phylogenetic relationship to $P$. fellutanum, $P$. thiersii and $P$. brocae based on parsimony analysis of multilocus DNA sequences. Mycologia 97: 659-666.

- 1992. Neosartorya pseudofischeri sp. nov. and its relationship to other species in Aspergillus section Fumigati. Mycol Res 96:547-554.

- 2004. Multilocus DNA sequence analysis shows that Penicillium biourgeianum is a distinct species closely related to Penicillium brevicompactum and $P$. olsonii. Mycol Res 108:434-440.

Pitt JI. 1980. The genus Penicillium and its teleomorphic states Eupenicillium and Talaromyces. New York: Academic Press. 634 p.

-1985. A laboratory guide to common Penicillium species. North Ryde: CSIRO Division of Food Processing.

Ramirez C. 1982. Manual and atlas of the Penicillia. New York: Elsevier Biomedical Press. 874 p.

Raper KC, Thom C. 1949. A manual of the Penicillia. Baltimore, Maryland: Williams \& Wilkins Co. 875 p.

Ridgway R. 1912. Color standards and color nomenclature. Washington, D.C.: Published by the author. 43 p. 53 plates.

Samson RA, Frisvad JC. 2004. Penicillium subgenus Penicillium: new taxonomic schemes, mycotoxins and other extrolites. Stud Mycol 49:1-260.

Serra R, Braga A, Venâncio A. 2005. Mycotoxin-producing and other fungi isolated from grapes for wine production, with particular emphasis on ochratoxin A. Res Microbiol 156:515-521.

_- Cabañes FJ, Perrone G, Castellá G, Venâncio A, Mulè G, Kozakiewicz Z. 2006a. Aspergillus ibericus: a new species of section Nigri isolated from grapes. Mycologia 98:295-306.

—_, Mendonça C, Venâncio A. 2006b. Fungi and ochratoxin A detected in healthy grapes for wine production. Lett Appl Microbiol 42:42-47.

Swofford DL. 2003. PAUP*: phylogenetic analysis using parsimony (*and other methods). Version 4. Sunderland, Massachusetts: Sinauer Associates.

Taylor JW, Jacobson DJ, Kroken S, Kasuga T, Geiser DM, Hibbett DS, Fisher MC. 2000. Phylogenetic species recognition and species concepts in fungi. Fun genet biol 31:21-32.

Thom C. 1930. The Penicillia. Baltimore, Maryland: Williams \& Wilkins Co. 644 p.

Thompson JD, Higgins DG, Gibson TJ. 1994. Clustal V: 
improving the sensitivity of progressive multiple sequence alignments through sequence weighting, position-specific gap penalties and weight matrix choice. Nucl Acid Res 22:4673-4680.

Wang H, Gloer JB, Wicklow DT, Dowd PF. 1995. Aflavinines and other antiinsectan metabolites from the ascostro- mata of Eupenicillium crustaceum and related species. Appl Environment Microbiol 61:4429-4435.

Wicklow DT, Dowd PF, Gloer JB. 1994. Antiinsectan effects of Aspergillus metabolites. In: Powell KA, Renwick A, Peberdy JF, eds. The genus Aspergillus. New York: Plenum Press. p 313-320. 